\title{
Sistematik Review Aktivitas Buah Pare (Momordica charantia L.) Terhadap Target Molekuler Antidiabetes
}

\section{Systematic Review The Activity Bitter Melon (Momordica Charantia L.) Against Molecular Targets Antidiabetic}

\author{
Mega Ayu Kusniawati, Rina Herowati, Gunaman Pamudji Widodo \\ Program Studi S2 Farmasi, Universitas Setia Budi \\ *Corresponding author: megaayukusniawati@gmail.com
}

(tanggal diterima: 17-09-2020, tanggal disetujui: 19-10-2021)

\section{INTISARI}

Diabetes melitus (DM) adalah penyakit kronis terjadi ketika pankreas tidak menghasilkan cukup insulin atau tubuh tidak dapat menggunakan insulin yang dihasilkan secara efektif. Tujuan untuk mengetahui aktivitas buah pare terhadap target molekuler antidiabetes secara sistematik review.

Metode yang digunakan sistematik review dengan membuat PRISMA ceklis dan diagram flow, menetapkan kriteria inklusi-eksklusi, search engine serta kata kunci untuk mendapatkan data yang relevan. Data yang diperoleh berupa hasil penelitian primer yang disajikan dalam tabel ekstraksi data, selanjutnya ditelaah secara komprehensif.

Hasil menunjukkan senyawa charantin, cucurbitacin, dan momordicoside D secara bersamaan mengaktivasi reseptor TGR5 dan GLP1 untuk menghambat DPP4, senyawa cucurbitane 25-0-methylkaraviagein D dikaitkan dengan keberadaan - $\mathrm{OH}$ memiliki aktivitas penghambatan

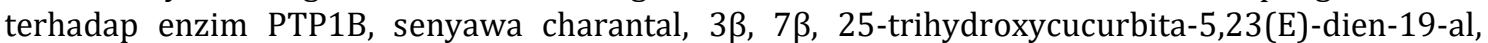

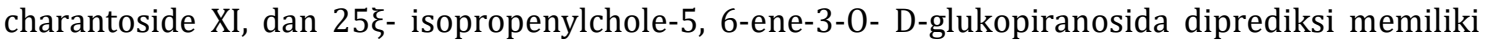
afinitas mengikat sisi aktif protein sehingga menghambat $\alpha$-glukosidase, dan senyawa charantin, vicine, polypeptide-p, 5-,19-epoxy-3-, 25-dihydroxycucurbita-6,23 (E) -diene dan 3- 7-, 25trihydroxycucurbita-5,23 (E)-dien-19-al. dapat meningkatkan jumlah GLUT4 pada permukaan sel

Kata kunci : Momordica charantia; DPP4; PTP1B; $\alpha$-glukosidase, GLUT4.

\begin{abstract}
Diabetes mellitus (DM) is a chronic disease that occurs either when the pancreas does not produce enough insulin, or when the body cannot effectively use the insulin it produces. The purpose activity of bitter melon fruit against molecular targets antidiabetic in literatre review.

The method of systematic evaluation is to make a PRISMA checklist and flow chart, determine the inclusion and exclusion criteria, search engines and keywords to obtain relevant data. The data was obtained from the primary research results presented in the data extraction table, and then was analyzed comprehensively.

The charantin, cucurbitacin, dan momordicoside D compound from bitter melon fruit has activating the TGR5 and GLP1 receptor simultaneously inhibiting DPP4. The cucurbitane 25-0methylkaraviagein $\mathrm{D}$ the of bitter melon fruit has inhibitory activity against the PTP1B enzyme which

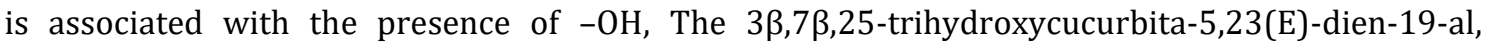

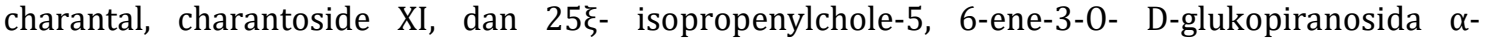
glucosidase predicted to have inhibitory activity of binding to the active side of the protein. The vicine, polypeptide-p, 5-,19-epoxy-3-, 25-dihydroxycucurbita-6,23 (E) -diene dan 3-7-,25trihydroxycucurbita-5,23 (E)-dien-19-al can increase the amount of GLUT4 on the cell surface.
\end{abstract}

Keyword : Momordica charantia; DPP4; PTP1B; $\alpha$-glukosidase, GLUT4 


\section{PENDAHULUAN}

Diabetes melitus (DM) adalah penyakit yang ditandai ketika pankreas tidak menghasilkan insulin yang cukup, atau tubuh tidak dapat menggunakan insulin yang dihasilkan secara efektif atau keduanya. Indonesia menempati peringkat ke tujuh dunia untuk prevalensi penderita DM, dengan jumlah estimasi orang sebesar 10 juta. Mayoritas penderita dengan DM dipengaruhi oleh diabetes tipe 2. DM tipe 2 terjadi hampir seluruhnya di antara orang dewasa, tetapi sekarang terjadi pada anak-anak juga [1]. DM tipe 2 merupakan suatu keadaan hiperglikemi yang dikarakterisasi oleh resistensi insulin atau defisiensi relatif sekresi insulin atau bahkan keduanya [2]. Tatalaksana dari DM tipe 2 adalah terkontrolnya kadar gula darah, sehingga menurunkan komplikasi. Obat antidiabetes yang ada di antara konsumen memiliki target molekuler yang berbeda-beda, umumnya bekerja meningkatkan sekresi insulin dan sensitivitas reseptor insulin. Namun penggunaan jangka panjang sering menimbulkan masalah, terutama efek samping, yang juga berdampak menurunkan kepatuhan pasien. Penelitian terus dilakukan untuk mencari target molekuler baru dalam terapi DM.

Pemanfaatan obat tradisional salah satunya buah pare. Buah pare merupakan jenis buah yang bermanfaat karena memiliki nilai ekonomi yang tinggi sebagai tanaman pangan dan bahan obat tradisional. Kandungan kimia buah pare yang berkhasiat dalam pengobatan adalah saponin, flavonoid, polifenol, alkaloid, triterpenoid, momordisin, glikosida cucurbitacin, charantin, asam butirat, asam palmitat, asam linoleat, dan asam stearat [3]. Menurut hasil penelitian [4] pare maserasi dengan etanol 70\%, granulometri hingga $710 \mu \mathrm{m}$ dan rasio plant: solvent 1.5: 10. Dalam kondisi ini, larutan ekstraktif terpilih mengandung 0,666g\% total flavonoid dinyatakan sebagai kuersetin. Menurut penelitian [5] pare mengandung senyawa n-tetradekana, metil dodekanoat, metilheksadekanoat, etil heksadekanoat, etiloktadekanoat, metil-9-oktadekenoat, mono(2-etilheksil)-1,2 benzena dikarboksilat, , metil oktadekanoat, metil-9cis-11trans-13trans oktadekatrienoat, metil-9,12oktadekadienoat dan mono (2-etilheksil)-1,2 benzena dikarboksilat.

Beberapa penelitian molekuler sebagai pencarian agent antidiabetes baru yang poten dan memiliki profil farmakologis yang baik, menurut penelitian [3] ekstrak etanol buah pare 2\% pada dosis $100 \mathrm{mg} / \mathrm{kg}$ bb sebanding dengan glibenklamid dapat menurunkan glukosa darah. Menurut [6] pemberian fraksi 1 nheksana buah pare, mampu menurunkan kadar glukosa darah tikus. Pada ekstrak buah pare yang mempunyai sifat kelarutan non polar berpotensi menurunkan kadar glukosa darah. Menurut penelitian [5] fraksi n-heksana ekstrak etanol buah pare aktif menurunkan kadar glukosa darah pada tikus putih jantan (Rattus novergicus) pada hari ke-7. Menurut penelitian [7] menyimpulkan bahwa ekstrak protein dari dua varietas pare memiliki aktivitas penghambatan $\alpha$ amylase dan $\alpha$-glukosidase secara in vitro persentase penghambatan $60-66 \%$, IC50 sebesar $0,26-0,29 \mathrm{mg} / \mathrm{ml}$ dan secara in vivo kedua ekstrak protein secara signifikan mengurangi glukosa darah puncak dan area di bawah kurva pada tikus diabetes yang diinduksi Streptozotocin, yang secara oral dibandingkan dengan pati dan sukrosa. 
DPP-4 (dipeptidly peptidase-4) merupakan enzim yang menghidrolisis Glukagon-Like Peptide-1 (GLP1), suatu hormon inkretin yang diekskresikan di saluran cerna GLP1 berperan dalam metabolisme tubuh, meliputi sekresi insulin, peningkatan massa sel $\beta$-pankreas, sekresi glucagon, dan mengurangi pengosongan lambung [8]. PTP1B (protein tyrosine phosphatase 1B) merupakan target terapi penting yang berhubungan dengan DM tipe 2 karena kemampuannya memodulasi jalur sinyaling insulin dan leptin [9]. $\alpha$-glucosidase merupakan anggota enzim hidrolase glikosida yang memutuskan ikatan glikosidik dari substrat sehingga mampu memecah glikogen dan menyebabkan peningkatan penyerapan karbohidrat [10]. Glukokinase adalah enzim yang terdapat di hati dan pancreas, berfungsi untuk memfosforilasi glukosa. Apabila kekurangan enzim ini dapat menyebabkan DM tipe 2 pada usia dini [11]. GLUT 4 adalah suatu transporter glukosa yang ada pada otot dan jaringan adipose, dimana tugas GLUT 4 ini untuk melakukan uptake glukosa yang diperantarai oleh insulin. . PI 3-kinase merupakan protein yang penting dalam translokasi GLUT 4 ke membrane sel pada sel otot dan adipose dan menginduksi enzim-enzim yang bekerja pada downstream [12]. Tujuan penelitian untuk mengetahui bagaimana aktivitas buah pare dalam menghambat enzim DPP4, PTP1B, $\alpha$-glukosidase, meningkatkan kadar GLUT secara sistematik review.

\section{METODE PENELITIAN}

Metode yang digunakan sistematikk review. Sistematik review yaitu membuat PRISMA checklist dan diagram flow, menetapkan kriteria inklusi-eksklusi, search engine serta kata kunci pencarian artikel penelitian. Hal tersebut bertujuan untuk memberikan tuntunan dalam melakukan review dan memberikan batas pencarian terhadap artikel penelitian yang relevan. Data yang diperoleh berupa hasil penelitian primer, tersaji dalam tabel ekstraksi data yang memuat judul, subjek, parameter, metode dan hasil penelitian, kemudian data dianalisis secara komprehensif.

\section{HASIL DAN PEMBAHASAN}

Analisis sistematis dan tinjauan literatur penelitian yang berkaitan dengan buah pare yang digunakan untuk aktivitas antidiabetes target molekuler diseluruh dunia antara tahun 2005-2020. Strategi yang digunakan untuk pencarian literatur penelitian berbasis web. Studi mekanisme atau pengujian secara in vitro, in vivo, in silico dikumpulkan dengan dua pendekatan pencarian yang berbeda, termasuk: Membahas pengujian aktivitas dan mekanisme kerja antidiabetes dari buah pare membahas aktivitas antidiabetes dari buah pare terkait mekanisme kerjanya pada enzim $\alpha$-glukosidase atau $\alpha$-amilase, DPP4, PTP1B, GLUT. Artikel jurnal yang diterbitkan menggunakan basis data ilmiah internasional termasuk PubMed, Web of Science, Google Scholar. Pencarian literatur menggunakan istilah kunci berikut: momordica charantia or momordica alpha glucosidase/dipeptidyl peptidase-4 (DPP4)/protein tirosin pospatase-1B (PTP1B), momordica charantia GLUT transport in vitro. Informasi yang relevan dikumpulkan dalam tabel 2. 
Tabel 2. Tabel ekstraksi data aktivitas buah pare terhadap target molekuler antidiabetes

\begin{tabular}{|c|c|c|c|c|c|}
\hline Subjek & $\begin{array}{l}\text { Tahun } \\
\text { publikasi }\end{array}$ & $\begin{array}{c}\text { Parameter yang } \\
\text { diuji }\end{array}$ & $\begin{array}{l}\text { Metode } \\
\text { uji }\end{array}$ & Hasil & Sitasi \\
\hline $\begin{array}{c}\text { Ekstrak buah } \\
\text { pare } \\
\text { Momordica } \\
\text { charantia }\end{array}$ & 2009 & $\begin{array}{l}\text { resistensi insulin } \\
\text { dan protein } \\
\text { kerangka otot } \\
\text { GLUT4 pada tikus } \\
\text { yang diberi } \\
\text { fruktosa }\end{array}$ & In vivo & $\begin{array}{c}\text { Hasil dari ekstrak buah pare } \\
\text { menghasilkan perubahan } \\
\text { ekspresi PPAR dan GLUT4 } \\
\text { pada tikus yang diberi diet } \\
\text { tinggi fruktosa }\end{array}$ & [12] \\
\hline $\begin{array}{c}\text { Ekstrak buah } \\
\text { pare }\end{array}$ & 2009 & $\begin{array}{l}\text { Potensial } \\
\text { penyerapan } \\
\text { glucose dan up- } \\
\text { regulate Glut-4, } \\
\text { PPAR_dan PI3K }\end{array}$ & $\begin{array}{l}\text { In vitro, } \\
\text { in silico }\end{array}$ & $\begin{array}{c}\text { Ekstrak klorofom buah pare } \\
\text { konsentrasi } 6 \text { g/ml } \\
\text { menunjukkan efek penaikan } \\
\text { yang signifikan, masing- } \\
\text { masing, sebesar } 3,6-, 2,8-\text { dan } \\
\text { 3,8 pada target Glut-4, PPAR } \\
\text { dan PI3K dalam transportasi } \\
\text { glukosa. }\end{array}$ & [20] \\
\hline $\begin{array}{c}\text { Buah } \\
\text { Momordica } \\
\text { charantia }\end{array}$ & 2010 & $\begin{array}{l}\text { Penghambatan } \\
\text { glikosida tipe } \\
\text { triterpene } \\
\text { terhadap Enzim } \alpha \\
\text { glucosidase }\end{array}$ & In silico & $\begin{array}{l}\text { Senyawa Momordicoside M } \\
\text { dan momordicoside A } \\
\text { memiliki aktivitas } \\
\text { penghambatan yang moderat } \\
\text { terhadap } \alpha \text {-glucosidase }\end{array}$ & [18] \\
\hline $\begin{array}{l}\text { Buah pare } \\
\text { Momordica } \\
\text { charantia }\end{array}$ & 2011 & $\begin{array}{c}\text { Dimerisasi } \\
\text { piceatannol oleh } \\
\text { buah pare } \\
\text { pirokside } \\
\text { penghambatanEn } \\
\text { zim } \alpha \text {-glucosidase }\end{array}$ & In vitro & $\begin{array}{c}\text { Dimer piceatannol } \\
\text { menunjukkan aktivitas } \\
\text { penghambatan } \alpha \text {-glukosidase } \\
\text { pada ikatan rangkap trans, } \\
\text { cincin tetrahydrofuran, dan } \\
\text { dihydroxyls dan M. charantia } \\
\text { peroxidase memiliki aktivitas } \\
\text { biotransformasi enzimatik } \\
\text { stilbena }\end{array}$ & [19] \\
\hline $\begin{array}{c}\text { Buah pare } \\
\text { Momordica } \\
\text { charantia }\end{array}$ & 2014 & $\begin{array}{l}\text { Senyawa baru } \\
\text { dari produk } \\
\text { hidrolisis } \\
\text { Penghambatan } \\
\text { PTP1B }\end{array}$ & In vitro & $\begin{array}{c}\text { Senyawa 5a, 19S-epoxy- } \\
\text { 19,23- dimethoxycucurbita- } \\
\text { 6,24-dien-3b-ol (1), 5a, 19R- } \\
\text { epoxy-19,23- } \\
\text { dimethoxycucurbita-6,24- } \\
\text { dien-3b-ol(2), 5b,19S-epoxy- } \\
\text { 19,23-dimethoxycucurbita- } \\
\text { 6,24-dien-3b-ol (4), } \\
\text { (19R,23E)-5ß,19-epoxy-19- } \\
\text { methoxy-cucurbita-6,23,25- } \\
\text { trien-3ß-o-l (7), (19R,23E)- } \\
\text { 5ß,19-epoxy-cucurbita- } \\
\text { 6,23,25-trien-3ß,19-diol (9) } \\
\text { memiliki penghambatan } \\
\text { PTP1B }\end{array}$ & [15] \\
\hline $\begin{array}{l}\text { Dua varian } \\
\text { buah pare }\end{array}$ & 2016 & $\begin{array}{l}\text { Penghambatan } \alpha- \\
\text { glucosidase }\end{array}$ & $\begin{array}{c}\text { in vitro } \\
\text { dan in } \\
\text { vivo }\end{array}$ & $\begin{array}{c}\text { Buah pare menghamnat } \\
\text { secara in vitro (66 hingga } \\
69 \% \text { ) dan IC50 (0,26 hingga } \\
0,29 \mathrm{mg} / \mathrm{ml}) \text {. ekstrak buah } \\
\text { pare signifikan mengurangi } \\
\text { glukosa darah tikus diabetes } \\
\text { yang diinduksi Streptozotocin, } \\
\text { yang secara oral ditantang } \\
\text { dengan pati dan sukrosa. }\end{array}$ & [7] \\
\hline
\end{tabular}




\begin{tabular}{|c|c|c|c|c|c|}
\hline Subjek & $\begin{array}{l}\text { Tahun } \\
\text { publikasi }\end{array}$ & $\begin{array}{c}\text { Parameter yang } \\
\text { diuji }\end{array}$ & $\begin{array}{c}\text { Metode } \\
\text { uji }\end{array}$ & Hasil & Sitasi \\
\hline $\begin{array}{l}\text { Buah pare } \\
\text { golongan } \\
\text { triterpenoid }\end{array}$ & 2017 & $\begin{array}{l}\text { penghambatan } \\
\text { enzim } \alpha- \\
\text { glukosidase, } \\
\text { PTP1B dan } \alpha- \\
\text { aamylase }\end{array}$ & In silico & $\begin{array}{l}\text { Senyawa yang terdapat dalam } \\
\text { buah pare ada } 21 \text { senyawa } \\
\text { antaranya diperoleh dua } \\
\text { glikosida triterpen tipe } \\
\text { cucurbitane (1 2) memiliki } \\
\text { aktivitas penghambatan } \\
\text { enzim } \alpha \text {-glukosidase, PTP1B, } \\
\text { IC50 masing-masing 10,19, } \\
28,55 \text {, dan } 20,20 \mathrm{lM}\end{array}$ & [14] \\
\hline $\begin{array}{l}\text { Ekstrak buah } \\
\text { pare golongan } \\
\text { triterpenoid }\end{array}$ & 2018 & $\begin{array}{c}\text { Aktivitas } \\
\text { penghambatanEn } \\
\text { zim alpha } \\
\text { glukosidase }\end{array}$ & in vitro & $\begin{array}{c}\text { Hasil penelitian menunjukkan } \\
\text { bahwa ekstrak kaya terpenoid } \\
\text { memiliki IC50 tinggi } 1,60 \\
\text { mg/mL aktivitas terhadap } \alpha \text { - } \\
\text { glukosidase }\end{array}$ & [16] \\
\hline $\begin{array}{c}\text { Senyawa } \\
\text { tuunan buah } \\
\text { pare }\end{array}$ & 2018 & $\begin{array}{c}\text { Studi mekanisme } \\
\text { penghambatan } \\
\text { DPP4 }\end{array}$ & $\begin{array}{l}\text { In silico } \\
\text { dan in } \\
\text { vivo }\end{array}$ & $\begin{array}{l}\text { mekanisme buah pare yaitu } \\
\text { aktivasi reseptor TGR5 dan } \\
\text { GLP-1 dengan penghambatan } \\
\text { bersamaan DPP4 bertanggung } \\
\text { jawab atas sifat } \\
\text { antidiabetesnya adalah } \\
\text { karantin, cucurbitacin dan } \\
\text { momordicoside D dan semua } \\
\text { kelas saponin. }\end{array}$ & [13] \\
\hline $\begin{array}{l}\text { Senyawa tipe } \\
\text { cucurbitae } \\
\text { pada buah } \\
\text { pare }\end{array}$ & 2019 & $\begin{array}{l}\text { Penghambatan } \\
\text { alfa-glukosidase }\end{array}$ & $\begin{array}{l}\text { in vitro, } \\
\text { in silico }\end{array}$ & $\begin{array}{l}\text { Ekstrak etil asetat buah pare } \\
\text { yang diperoleh golongan } \\
\text { senyawa triterpen tipe } \\
\text { cucurbitane } 3 \beta, 7 \beta, 25- \\
\text { trihydroxycucurbita-5,23 (E) - } \\
\text { dien-19-al, charantal, } \\
\text { charantoside XI, dan } 25 \xi- \\
\text { isopropenylchole-5, 6-ene-3- } \\
\text { 0-D-glucopyranoside } \\
\text { penghambatan signifikan } \\
\alpha \text {-glukosidase sebanding } \\
\text { dengan acarbose. }\end{array}$ & [17] \\
\hline
\end{tabular}

Dipeptidyl-peptidase 4 (DPP4) adalah glikoprotein $110 \mathrm{kDa}$, yang diekspresikan pada permukaan berbagai sel. Eksopeptidase ini secara selektif membelah dipeptida $\mathrm{N}$-terminal dari berbagai substrat, termasuk sitokin, faktor pertumbuhan, neuropeptida, dan hormon incretin. Ekspresi DPP4 secara substansi tidak diatur dalam berbagai keadaan penyakit salah satunya diabetes militus. Karena hormon incretin, glukagon-like peptide-1 dan glukosa-dependent insulinotropic polypeptide (GIP), adalah pengatur utama sekresi insulin pascaprandial. Penghambatan DPP4 termasuk kelompok obat gliptin sebagai terapi tipe 2. Menurut penelitian [22] ekstrak metanol $(0,5 \mathrm{mg} / \mathrm{ml})$ buah pare menghambat aktivitas DPP4 $(53,25 \pm 0,04 \%)$ fenolik. Ekstrak buah pare mengandung beberapa inhibitor DPP4 baru dengan potensi antiperoksidatif dan dapat dikembangkan sebagai molekul terapeutik untuk diabetes mellitus tipe 2. Situs aktif DPP4 terletak di urutan Gly-Trp-Ser-Tyr-Gly dan merupakan bagian dari triad katalitik (Ser 630, Asp 708, His 740) dalam katalitik DPP4. Hormon GLP-1 dan GIP terletak diusus 
masing-masing dikeluarkan setelah asupan makanan dari sel-sel L dan $\mathrm{K}$ dari mukosa usus. Hormon tersebut berkontribusi sekitar $60 \%$ dari sekresi insulin postprandial dan bertanggung jawab atas efek incretin. Sementara DPP4 pada pasien DM secara cepat menonaktifkan GLP-1 dan GIP. Penghambatan DPP4 untuk memperpanjang dan meningkatkan aktivitas GLP-1 dan GIP endogen, yang berfungsi sebagai stimulator prandial penting yang berperan pada sekresi insulin dan regulator glukosa darah. Pada penelitian ini mengungkapkan bahwa konsentrasi ekstrak metanol buah pare mampu menghambatan DPP4. Menurut penelitian [13] Salah satu senyawa yang terkandung dalam buah pare yaitu cocorbitacin memiliki afinitas tertinggi dalam mengikat reseptor GLP-1 dan termasuk dalam golongan senyawa saponin.

Cucurbitan dalam golongan senyawa saponin menunjukkan afinitas tertinggi penghambatan DPP4 yaitu sebesar $(-8,4 \mathrm{kkal} / \mathrm{mol})$ bila dibandingkan dengan obat standar omarigliptin sebesar $(-9,3 \mathrm{kkal} / \mathrm{mol})$. Senyawa momordicosides $\mathrm{D}$ golongan senyawa saponin memiliki afinitas paling tinggi mengikat TGR5 sebesar (-9,3 $\mathrm{kkal} / \mathrm{mol})$ bila dibandingkan dengan asam kolat sebagai agonis sebesar $(-7,2$ $\mathrm{kkal} / \mathrm{mol}$ ). Selama stimulasi DPP4 interaksi senyawa kimia buah pare distabilkan dengan ikatan hidrogen dan hidrofobik. Situs aktif DPP4 terdapat dua residu yaitu Tyr-752 dan Lys-554 yang terlibat dalam pembentukan ikatan hidrogen dengan charantin. Interaksi hidrofobik juga berkontribusi pada interaksi charantind engan residu asam amino (Asp 545, Trp 627, Trp 629, Glu 206, Tyr 547, 740, Arg 125, Tyr 666, Phe 357, Ser 630, Glu 205, Tyr 662, Tyr631, Asn 710) dalam situs aktif DPP-4. Glu1169, Glu1170, Ser1172, Lys1250, Arg1257 adalah residu penting untuk ikatan hidrogen dengan GLP-1 dan delapan residu bertanggung jawab untuk interaksi hidrofobik (Phe1254, Tyr 1173, Met 1136, Asn1200, His1201, Trp1247, Phe1246, Tyr1242). Interaksi ikatan hidrogen momorcosides D dengan TGR5 yang ditingkatkan oleh residu Arg830, Thr848 di situs aktif sebaliknya, dua belas residu bertanggung jawab atas interaksi hidrofobik dengan Momorcosides D (Val 827, Asp 860, Met 715, Arg 849, Pro 828, Ala 716, Pro 824, Glu 823, Ile 843, Leu 796, Asp 795, Phe 794). Hasil studi in silico menunjukkan bahwa charantin, cucurbitacin dan momordicosides D mungkin merupakan senyawa antidiabetik utama di buah pare dan mekanisme kerja senyawa ini adalah melalui aktivasi reseptor TGR5 dan GLP-1 dengan penghambatan bersamaan DPP4. Senyawa bioaktif yang mungkin bertanggung jawab atas antidiabetik adalah saponin (charantin, cucurbitacin, dan momordicoside D).

Peran PTP1B dalam pensinyalan insulin pada DM tipe 2 menunjukkan bahwa PTP1B adalah regulasi metabolik dan target farmakologis untuk diabetes tipe 2 . PTP1B dapat mengkatalisis insulin receptor (IR) dan insulin receptor substrates (IRS) dephosphorylation, mengkoordinasikan keseimbangan antara fosforilasi dan defosforilasi residu tirosin, yang mengakibatkan downregulasi transduksi sinyal insulin. Selain itu, PTP1B dapat mendeosforilasi JAK2 dan STAT3 yang diaktifkan, dan mencegah transduksi sinyal leptin. Ekspresi PTP1B yang tinggi mempengaruhi aktivitas PTKs yang mengakibatkan insulin gagal bergabung dengan IR, menyebabkan resistensi insulin dan resistensi leptin, serta menyebabkan diabetes 
tipe 2 dan obesitas. Penghambat PTP1B dan terapi diabetes tipe 2 PTP1B adalah PTP intraseluler, terlibat dalam regulasi negatif insulin serta pensinyalan leptin. PTP1B telah muncul sebagai target terapeutik yang divalidasi untuk pengobatan diabetes tipe 2 dan kelainan metabolik. PTP1B telah dihambat secara eksperimental menggunakan berbagai mekanisme dan senyawa kimia. Inhibitor PTP1B berpotensi meningkatkan resistensi insulin dan menormalkan glukosa plasma dan kadar insulin tanpa menyebabkan hipoglikemia. Metabolit sekunder mengandung keragaman struktural dan jenis sifat obat dan banyak obat secara langsing dan tidak langsung berasal dari produk alami. Produk alami dianggap sebagai sumber penting untuk obat baru penghambatan PTP1B. Berbagai macam prodk alami telah dilaporkan dengan aktivitas penghambatan PTP1B seperti penelitian [14] senyawa golongan triterpenoid cucurbitane 25-0-methylkaraviagein D memiliki aktivitas penghambatan terkuat terhadap PTP1B.

Menurut penelitian [15] telah mengisolasi dan memurnikan konstituen bioaktif melalui hidrolisis asam dari buah pare dan mengevaluasi efek dari konstituen buah pare terhadap aktivitas PTP1B. Terdapat empat senyawa baru yaitu 5a, 19S-epoxy-19,23- dimethoxycucurbita-6,24-dien-3b-ol (1), 5a, 19R-epoxy19,23-dimethoxycucurbita-6,24-dien-3b-ol(2),

dimethoxycucur- bita-6,24-dien-3b-ol (3) dan 5b,19S-epoxy-19,23dimethoxycucurbita-6,24-dien-3b-ol (4), dari delapan senyawa yang diketahui dan telah diisolasi dari produk terhidrolisis asam dari buah pare. Dari hasil pengujian aktivitas, hanya senyawa 5a, 19S-epoxy-19,23- dimethoxycucurbita-6,24-dien-3bol(1), 5a,19R-epoxy-19,23-dimethoxycucurbita-6,24-dien-3b-ol(2), 5b,19S-epoxy19,23-dimethoxycucurbita-6,24-dien-3b-ol (4), (19R,23E)-5ß,19-epoxy-19methoxy-cucurbita-6,23,25-trien-3ß-o-l(7) dan (19R,23E)-5ß,19-epoxy-cucurbita6,23,25-trien-3ß,19-diol (9) yang menunjukkan penghambatan signifikan pada PTP1B, dengan tingkat penghambatan sebesar 77\%, 62\%, 62\%, 60\% dan 68\%. Efisiensi penghambatan terhadap PTP1B dari senyawa-senyawa ini bahkan lebih kuat daripada $\mathrm{Na}_{3} \mathrm{VO}_{4}$, sebagai kontrol positif yang digunakan dalam penelitian ini. Selain itu, senyawa 5b,19Repoxy-19,23-dimethoxycucur- bita-6,24-dien-3b-ol (3), (19R,23E)-5b,19-epox y-19,25-dimethoxycucurbita-6,23-dien-3b-ol (6) dan 5b,19epoxy-cucurbita-6,23(E)-dien-3b,25-diol (10) menunjukkan tingkat aktivitas penghambatan yang relatif moderat terhadap PTP1B, menghasilkan masing-masing 40\%, 37\% dan 52\% penghambatan. Analisis Spatial Autoregresive (SAR) menunjukkan bahwa senyawa dengan kelompok substituen -OH dalam rantai samping yaitu senyawa (19R,23E)-5b,19-epoxy-19-methoxy-cucurbita-6,23-dien3b,25-diol (5) dan 3b,7b,25-trihydroxy-cucurbita-5(23E)-diene-19-al (11) tidak memiliki efisiensi penghambatan yang signifikan pada PTP1B. Sementara senyawa $(1,2,4,7$ dan 9) tanpa kelompok substitusi -OH dalam rantai samping menunjukkan penghambatan yang lebih baik terhadap aktivitas PTP1B. Hasil penelitian ini juga menunjukkan bahwa aktivitas penghambatan PTP1B dari triterpenoid tipe cucurbitanet dikaitkan dengan keberadaan kelompok - $\mathrm{OH}$ pada rantai samping serta jumlah kelompok -OH. PTP1B merupakan fosfatase yang bersifat sangat hidrofilik sehingga penghambatan PTP1B sebagian besar molekulnya bersifat 
sangat hidrofilik namun ada beberapa senyawa signifikan menghambat PTP1B sifatnya lipofilik. Sehingga pengaruh subtitusi -OH terhadap aktivitas PTP1B masih belum terlalu jelas dan perlu dilakukan penelitian selanjutnya.

Penghambatan $\alpha$-glukosidase menurut penelitian [7] buah pare secara in vitro dan in vivo dengan menggunakan ekstrak protein. Metode yang digunakan untuk pengujian in vitro menggunakan enzim alfa glukosidase dan dilanjutkan dengan uji in vivo induksi streptozotocin dan acarbose sebagai kontrol positif. Ekstrak protein buah pare menunjukkan aktivitas maksimum penghambatan terhadap $\alpha$-glukosidase pada konsentrasi 10\%. IC50 dari MCC, MCM dan acarbose berturut-turut adalah 0,298 $\pm 0,034,0,292 \pm 0,022$, dan 0,28 $\pm 0,019 \mathrm{mg} / \mathrm{ml}$. Penghambatan kompetitif, yang setara dengan Acarbose seperti yang ditunjukkan oleh persentase penghambatan in vitro sebesar 66 hingga 69\% dan nilai IC50 0,26 hingga $0,29 \mathrm{mg} / \mathrm{ml}$. Pada penelitian [16] ekstrak buah pare dengan kandungan triterpen memiliki IC 50 sebesar 1,45 mg/mL. Menurut penelitian [17] senyawa yang berhasil diisolasi dari ekstrak etil asetat adalah golongan senyawa triterpen tipe cucurbitane yang bertanggung jawab sebagai senyawa antidiabetes. Senyawasenyawa tersebut antara lain $3 \beta, 7 \beta, 25$-trihydroxycucurbita-5,23(E)-dien-19-al,

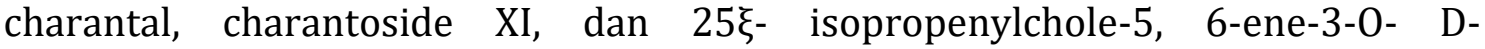
glukopiranosida Senyawa-senyawa ini telah dikarakterisasi dengan HR-ESIMS, 1D, dan 2D NMR. Semua senyawa menunjukkan penghambatan signifikan terhadap $\alpha-$ amilase dan $\alpha$-glukosidase yang sebanding dengan acarbose. Studi docking molekuler menunjukkan bahwa senyawa yang dimurnikan mampu mengikat ke situs aktif protein. Dimerisasi piceatannol dari Momordica charantia peroxidase (MCP) sebagai aktivitas penghambatan alfa glukosidase. Selain Stilbenes, terutama oligomer, memiliki potensi besar untuk menjadi agen antihiperglikemik. Penelitian [18] momordicoside $\mathrm{M}$ dan momordicoside A memiliki aktivitas moderat untuk penghambatan alfa glukosidase. Penelitian [19] delapan dimer stilbene, termasuk lima dimer baru, untuk pertamakalinya biotransformasi piceatannol menggunakan Momordica charantia peroxidase (MCP). Struktur mereka didirikan berdasarkan bukti spektroskopi. Dimer piceatannol ini menunjukkan potensi aktivitas penghambatan alfa glukosidase dan trans ikatan rangkap, cincin tetrahydrofuran dan dihydroxyls fenolik yang berdekatan. Biotransformasi enzimatik stilbena $\mathrm{M}$. charantia peroksidase (MCP) untuk menghasilkan stilbena oligomer sebagai pengembangan antihiperglikemik.

Peningkatan translokasi/ekspresi GLUT Menurut penelitian [20] glucose transporter 4 (GLUT4) adalah transporter glukosa utama yang diatur oleh insulin diekspresikan dalam otot rangka dan jaringan adiposa. Insulin merangsang pengambilan glukosa dalam sel-sel terutama menginduksi translokasi GLUT4 dari tempat penyimpanan intraseluler ke membran plasma. Resistensi insulin diketahui dengan berkurangnya pengambilan glukosa dan pemanfaatan oleh jaringan dan dikaitkan dengan berkurangnya ekspresi gen GLUT4. Gangguan ekspresi GLUT4, translokasi GLUT4 atau pensinyalan insulin dapat mempengaruhi penyerapan glukosa yang dirangsang oleh insulin, akan menghasilkan resistensi insulin dan hiperglikemia. Buah pare mengandung bahan kimia meliputi glikosida, saponin, 
alkaloid, triterpen, protein, dan steroid. Bahan kimia hipoglikemik pare adalah campuran dari steroid saponin yang dikenal sebagai charantin dan alkaloid. Beberapa kandungan kimia yang sudah terisolasi seperti charantins, a polipeptidap, momordin Ic, asam oleanolic 3-HAI-monodesmoside dan asam oleanolic 3-HAIglucuronide dari pare telah menunjukkan aktivitas hipoglikemik. Ekstraksi protein dan imunoblot untuk penentuan GLUT4 dilakukan pada otot rangka beku dari tikus menggunakan metode Klip yang dimodifikasi. Hasil penelitian menunjukkan bahwa ekstrak buah pare secara efektif mengendalikan hiperglikemia dan hiperinsulinemia pada hewan uji yang resisten insulin yang diinduksi fruktosa kerja dari kandungan kimia dalam pare mirip dengan sensitizer insulin konvensional, yang bertindak sebagai agonis PPAR gama. Buah pare menunjukkan dua mekanisme yang menghasilkan peningkatan kepekaan reseptor insulin, dan peningkatan penyerapan glukosa ke dalam otot yang mengakibatkan penurunan kadar glukosa. Peningkatan dalam kontrol glikemik dari buah pare berkaitan dengan peningkatan ekspresi mRNA GLUT4 dalam otot rangka melalui PPAR jalur tengah yang membuat peningkatan efisiensi penyerapan glukosa dan menekan peningkatan glukosa plasma. Peningkatan protein GLUT4 dalam membran plasma otot rangka bertanggung jawab atas dampak yang menguntungkan pada sensitivitas reseptor insulin. Level mRNA GLUT4 ternyata tidak berkorelasi terhadap kandungan protein. Buah pare juga meningkatkan jumlah GLUT4 pada permukaan sel, sehingga meningkatkan penyerapan glukosa dalam jaringan perifer, terutama otot rangka sehingga diduga pare merupakan kandidat untuk perlindungan terhadap diabetes tipe 2. Penelitian [21] pengujian dengan model in vitro menggunakan kultur sel L6 dengan ekstrak air dan kloroform, ekstrak buah pare pada dosis $6 \mathrm{~g} / \mathrm{ml}$ optimal memiliki aktivitas terhadap peningkatan Glut-4, memperkuat transpor glukosa berperan efektif dari fitokimia umum yang ada dalam dua ekstrak[20].

\section{KESIMPULAN}

Berdasarkan kajian sistematik review buah pare senyawa charantin, cucurbitacin, dan momordicoside D secara bersamaan mengaktivasi reseptor TGR5 dan GLP1 untuk menghambat DPP4, senyawa cucurbitane 25-0-methylkaraviagein $\mathrm{D}$ dikaitkan dengan keberadaan $-\mathrm{OH}$ memiliki aktivitas penghambatan terhadap enzim PTP1B, senyawa $3 \beta, 7 \beta, 25$-trihydroxycucurbita-5,23(E)-dien-19-al,

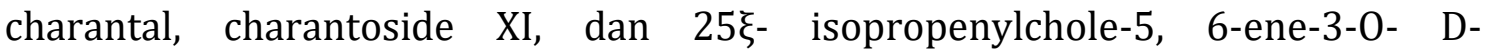
glukopiranosida diprediksi memiliki afinitas mengikat sisi aktif protein sehingga menghambat $\alpha$-glukosidase, dan senyawa yang dapat meningkatkan jumlah GLUT4 pada permukaan sel yaitu charantin, vicine, polypeptidep, 5-,19-epoxy-3-,25dihydroxycucurbita-6,23(E)-diene dan 3-7-,25 trihydroxycucurbita-5,23 (E)-dien19-al.

\section{DAFTAR PUSTAKA}

[1]. WHO. 2018. "World Health Organisation." Global Report on Diabetes: 88.

[2]. Schwinghammer, Terry L. 2015. Pharmacotherapy Handbook Chapter 10. Hypertension. 
[3]. Yuda I.K.A, Anthara M.S., Dharmayudha A.A.G.O. 2013. “Identifikasi Golongan Senyawa Kimia Estrak Etanol Buah Pare (Momordica Charantia) Dan Pengaruhnya Terhadap Penurunan Kadar Glukosa Darah Tikus Putih Jantan (Rattus Novergicus) Yang Diinduksi Aloksan." Buletin Veteriner Udayana 5(2): 87-95.

[4]. Nobre, Cristiane P., Fernanda N. Raffin, and Túlio F. Moura. 2005. "Standardization of Extracts from Momordica Charantia L. (Cucurbitaceae) by Total Flavonoids Content Determination." Acta Farmaceutica Bonaerense 24(4): 562-66.

[5]. Kartini, Ketut, I Swantara, and I Suartha. 2015. "Isolasi Dan Identifikasi Senyawa Aktif Ekstrak Etanol Buah Pare (Momordica Charantia L.) Yang Dapat Menurunkan Kadar Glukosa Darah." CAKRA KIMIA (Indonesian EJournal of Applied Chemistry) 3(2): 32-38.

[6]. Suartha, I Nyoman, I Made Dira Swantara, and Wiwik Susanah Rita. 2016. "Ekstrak Etanol Dan Fraksi Heksan Buah Pare (Momordica Charantia) Sebagai Penurun Kadar Glukosa Darah Tikus Diabetes.” Jurnal Veteriner 17(1): 30-36.

[7]. Poovitha, Sundar, and Madasamy Parani. 2016. "In Vitro and in Vivo $\alpha$ Amylase and $\alpha$-Glucosidase Inhibiting Activities of the Protein Extracts from Two Varieties of Bitter Gourd (Momordica Charantia L.)." BMC Complementary and Alternative Medicine 16(Suppl 1): 1-8. http://dx.doi.org/10.1186/s12906-016-1085-1.

[8]. Ekayanti, Meiliza, Rani Sauriasari, and Berna Elya. 2018. "Dipeptidyl Peptidase IV Inhibitory Activity of Fraction from White Tea Ethanolic Extract (Camellia Sinensis (L.) Kuntze) Ex Vivo." Pharmacognosy Journal 10(1): 19093.

[9]. Saifudin, Azis, Shigetoshi Kadota, and Yasuhiro Tezuka. 2012. "Protein Tyrosine Phosphatase 1B Inhibitory Activity of Indonesian Herbal Medicines and Constituents of Cinnamomum Burmannii and Zingiber Aromaticum." Journal of Natural Medicines 67(2): 264-70.

[10]. Kerru, Nagaraju, Ashona Singh-Pillay, Paul Awolade, and Parvesh Singh. 2018. "Current Anti-Diabetic Agents and Their Molecular Targets: A Review." European Journal of Medicinal Chemistry 152(May): 436-88.

[11]. Efanov, Alexander M. et al. 2005. "A Novel Glucokinase Activator Modulates Pancreatic Islet and Hepatocyte Function." Endocrinology 146(9): 36963701.

[12]. Gisela Wilcox. 2005. "Insulin and Insulin Resistance Gisela." Insulin and Insulin Resistance Gisela 22(2): 61-63.

[13]. Olalekan, Olalekan, O., Opeyemi, E., Orimoloye, M., Sam, O., Olalekan, A., \& Gbadura, I. (2018). Pathophysiology Potential use of bitter melon ( Momordica charantia ) derived compounds as antidiabetics : In silico and in vivo studies. Pathophysiology, 25(4), 327-333. https://doi.org/10.1016/j.pathophys.2018.05.003

[14]. Yue, Yue, J., Xu, J., Cao, J., Zhang, X., \& Zhao, Y. (2017). Cucurbitane 
triterpenoids from Momordica charantia L. and their inhibitory activity against $\alpha$-glucosidase, $\alpha$-amylase and protein tyrosine phosphatase $1 \mathrm{~B}$ (PTP1B). Journal of Functional Foods, 37, 624-631. https://doi.org/10.1016/j.jff.2017.07.041

[15]. Zeng, He, Y., Yang, D., Cao, J., Xia, X., Zhang, S., \& Bi, X. (2014). "European Journal of Medicinal Chemistry New Compounds from Acid Hydrolyzed Products of the Fruits of Momordica Charantia L . and Their Inhibitory Activity against Protein Tyrosine Phosphatas 1B." European Journal of Medicinal Chemistry 81: 176-80. http://dx.doi.org/10.1016/j.ejmech.2014.01.066

[16]. Sallau A. B., Yakubu R. N., Aliyu S. M., Salihu A., Boniface B. Y. 2018. "In Vitro Efect of Terpenoids-Rich Extract of Momordica Charantia on Alpha Glucosidase Activity." 25(3): 148-53. DOI: http://dx.doi.org/10.17533/udea.vitae.v25n3a05

[17]. Shivanagoudra, R., Perera, W. H., Perez, J. L., Athrey, G., Sun, Y., Jayaprakasha, G. K., \& Patil, B. S. 2019. "Bioorganic Chemistry Antidiabetic , AntiInflammatory Activities and in Silico Modeling Approaches." Bioorganic Chemistry 87(January): 31-42. https://doi.org/10.1016/i.bioorg.2019.02.040.

[18]. Hiem, N. X. N., Iem, P. V. K., Inh, C. V. M., An, K. B., Uong, X. C., Goc, T. M. N., Im, Y. H. K.2010. " $\alpha$-Glucosidase Inhibition Properties of Cucurbitane-Type Triterpene Glycosides from the Fruits of Momordica Charantia." 58(5): 72024. https://doi.org/10.1192/bjp.111.479.1009-a.

[19]. Wan, X., Wang, X., Yang, M., Wang, J., \& Kong, L. 2011. “Bioorganic \& Medicinal Chemistry Dimerization of Piceatannol by Momordica Charantia Peroxidase and $\alpha$-Glucosidase Inhibitory Activity of the Biotransformation Products." Bioorganic \& Medicinal Chemistry 19(17): 5085-92. http://dx.doi.org/10.1016/j.bmc.2011.07.032.

[20]. Kumar, Ramadhar, S Balaji, T S Uma, and P K Sehgal. 2009. "Fruit Extracts of Momordica Charantia Potentiate Glucose Uptake and Up-Regulate Glut-4, PPAR and PI3K." 126: 533-37. https://doi.org/10.1016/i.jep.2009.08.048

[21]. Shih, Chun-ching, Cheng-hsiu Lin, Wei-li Lin, and Jin-bin Wu. 2009. "Momordica Charantia Extract on Insulin Resistance and the Skeletal Muscle GLUT4 Protein in Fructose-Fed Rats." 123: 82-90. https://doi.org/10.1016/j.jep.2009.02.039

[22]. Singh, A. K., Jatwa, R., \& Joshi, J. A. Y. A. 2014. Cytoprottective and Dipepetidyl Peptidase IV (DPP-IV/CD26) Inhibitory Roles of Ocimun Sanctum and Momordica Charantia Extract. 7(2827). 